\title{
The Patentability of Stem Cells in Australia
}

\author{
Jenny Petering and Prue Cowin \\ FB Rice, Melbourne, Victoria 3000, Australia \\ Correspondence: jpetering@fbrice.com.au
}

The potential therapeutic applications of stem cells are unlimited. However, the ongoing political and social debate surrounding the intellectual property and patenting considerations of stem cell research has led to the implementation of strict legislative regulations. In Australia the patent landscape surrounding stem cells has evolved considerably over the past 20 years. The Australian Patents Act 1990 includes a specific exclusion to the patentability of human beings and of biological processes for their generation. However, this exclusion has received no judicial consideration to date, and so its scope and potential impact on stem cell patents is unclear.

$\mathrm{T}_{\mathrm{m}}^{\mathrm{h}}$ he stem cell era began with the first bone marrow transplants performed in human patients in 1956. Despite technological advancements and high expectations of stem cell therapies, stem cell research remains one of the most controversial topics in the community at both a social and ethical level, largely because of the nature of these cells. It is within this arena of public opinion that governments have felt the need to adopt policies and legislation to regulate such research. Like many other technologies and scientific discoveries, patents in the realm of stem cell research can promote research and innovation. However, the question remains as to whether the cost of these patents is too high a price to pay. Despite worldwide acceptance that a patent should be granted on the basis of novelty, originality, and industrial application, there remains no consensus on the patentability of human stem cells between jurisdictions.

\section{STEM CELL TECHNOLOGY}

According to IP Australia (2002; 2.9.3.5.1), stem cell technologies are to be considered and examined in the same way as other technical inventions. Much of the debate around the patentability of human stem cells has centered on the origin of the cells-in particular, embryonic stem cells and the destruction of a human embryo that has the capacity to develop into a human being. To appreciate what stem cells are patentable under Australian practice, it is important to understand the different types of stem cells that exist.

\section{Embryonic Stem Cells}

In general, embryonic stem cells have the ability to divide indefinitely and have the capacity to differentiate into other cell types. Totipotent

Editors: Salim Mamajiwalla and Rochelle Seide

Additional Perspectives on Intellectual Property in Molecular Medicine available at www.perspectivesinmedicine.org

Copyright (C) 2015 Cold Spring Harbor Laboratory Press; all rights reserved; doi: 10.1101/cshperspect.a020966

Cite this article as Cold Spring Harb Perspect Med 2015;5:a020966 
stem cells are derived from fertilized oocytes and cells of an embryo, up to about the eightcell stage. These cells have the inherent ability to differentiate into any human cell type and the extraembryonic placenta. Pluripotent stem cells are derived from the inner cell mass of the human blastocyst and have the capacity to differentiate into nearly all cell types in the body of a mature organism, that is, cells derived from any of the three germ layers: mesoderm and/or endoderm and/or ectoderm (Fig. 1). The specific lineage-commitment and differentiation pathway that these cells enter depends on various influences from mechanical influences and/or endogenous bioactive factors, such as growth factors, cytokines, and/or local microenvironmental conditions established by host tissues.

\section{Adult Stem Cells}

Adult stem cells, also known as somatic stem cells, are derived from tissues throughout the human body. Unlike embryonic stem cells, adult stem cells are considered to be multipotent as they have a more restricted differentiation potential and can only differentiate into closely related cell types. They are generally referred to by their tissue origin (such as mesenchymal stem cells). Adult stem cells were first identified in the mature primate brain in 1967 (Lewis 1968); however, the existence of adult stem cells in the brain had long been postulated following discovery of the process of neurogenesis (Altman and Das 1965). In addition to neural stem cells, several adult human stem cells have been identified, namely, mammary (Liu et al. 2005), intestinal (Van Der Flier and Clevers 2009), mesenchymal (Phinney and Prockop 2007), and olfactory (Murrell et al. 2005). The best-known adult stem cells are hematopoietic stem cells, which are derived from the bone marrow and give rise to all blood cell types.

Following the isolation of mouse embryonic stem cells in 1981 (Evans and Kaufman 1981;

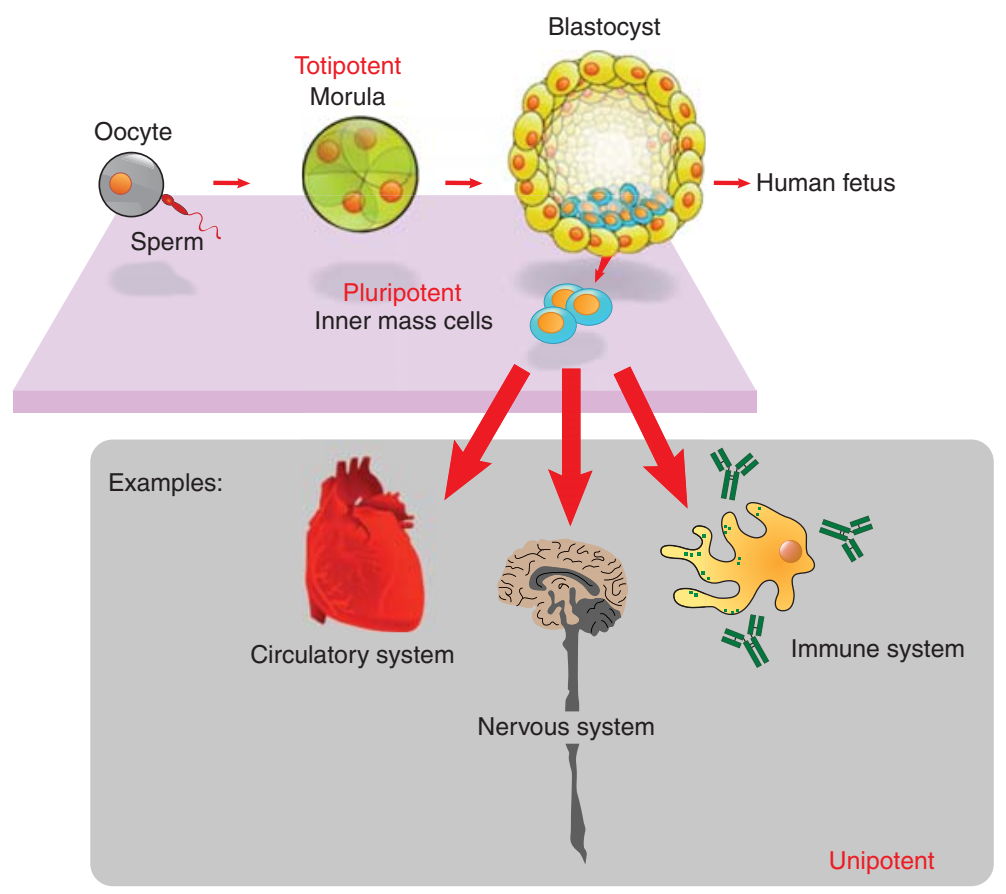

Figure 1. The origin of stems cells from developing embryos. (Image reprinted from English Wikipedia. Original work by Mike Jones for Wikipedia: http://en.wikipedia.org/wiki/Embryonic_stem_cell mediaviewer/File :Stem_cells_diagram.png. This file is licensed under the Creative Commons Attribution-Share Alike 2.5 Generic license http://creativecommons.org/licenses/by-sa/2.5/deed.en.) 


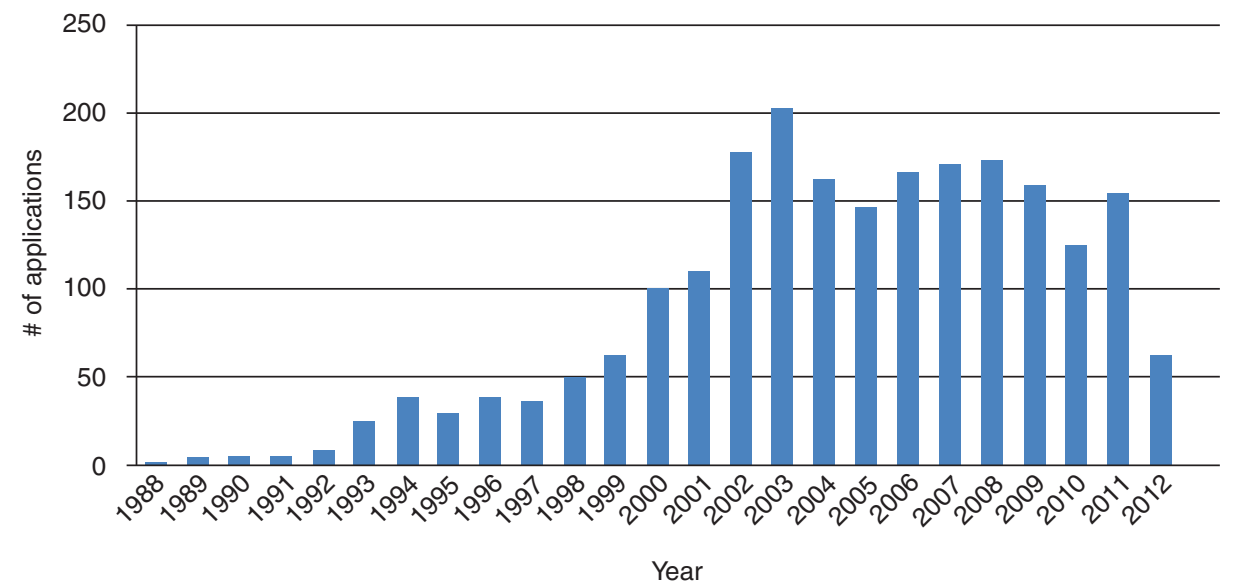

Figure 2. Number of Australian patent applications filed per year containing the phrase "stem cell" in the title, claims, or abstract (as of October 16, 2013).

Martin 1981), the isolation of human adult stem cells in 1992, and the isolation of human embryonic stem cells in 1998 (Thomson et al. 1998), the patent landscape surrounding stem cells in Australia has continued to evolve (Fig. 2). The number of stem cell patent applications filed with IP Australia peaked around 2002-2003; however, they appear to have declined since 2011.

\section{PATENTABILITY OF STEM CELLS IN AUSTRALIA}

\section{Patentable Subject Matter}

Patent protection provides an inventor with an exclusive right to limit commercial exploitation of an invention for a period of time, rather than permission to exploit the invention. The value of a patent is determined by the scope of the claims, and it is the claims that define the level of protection obtained. In Australia section 18 of the Patents Act 1990 (Cth) provides that a patentable invention is one that is novel, useful, involves an inventive step, and is a "manner of manufacture" within the meaning of section 6 of the Statute of Monopolies.

The meaning of "manner of manufacture" is not defined in the act and has been distilled by Australian case law. In particular, National Research Development Corporation (NRDC) v.
Commissioner of Patents (1959) (102 CLR 252; 1A IPR 63) has been described as a landmark decision or watershed moment with respect to patentable subject matter. The appeal in NRDC to the Full Court of Australia concerned whether or not a method for eradicating weeds from a crop area by the application of specific herbicides constituted a manner of manufacture. The court indicated that

... what is meant by a "product" in relation to a process is only something in which the new and useful effect may be observed. Sufficient authority has been cited to show that the "something" need not be a "thing" in the sense of an article; it may be any physical phenomenon in which the effect, be it creation or merely alteration, may be observed ...

The NRDC case was instrumental in establishing three distinct criteria for an invention to satisfy the "manner of manufacture" requirement. In particular, a patentable invention must: ${ }^{2}$

- result in an artificially created state of affairs;

- belong to the useful arts as distinct from the fine arts;

- have economic significance.

\footnotetext{
${ }^{1} N R D C$ (1959) (102 CLR 252; 1A IPR 63 at CLR 276 IPR 75).

${ }^{2}$ NRDC (1959) (102 CLR 252; 1A IPR 63 at CLR 275 IPR 75).
} 
Hence, with respect to patent law the term "manufacture" may be regarded simply as a descriptor for the subject matter for which a patent may be granted (Bodkin 2014). These principles are held in relation to all patentable subject matter; however, several categories have been explicitly excluded-namely, mere discoveries, ideas, scientific theories, mathematical algorithms, and laws of nature (IP Australia 2002; 2.9.2.5). The broad and general nature of this provision has required reinterpretation over time to keep pace with technological developments. In this way, the categories of inventions that satisfy the test have expanded over time.

One example of this expansion relates to biological inventions, specifically living organisms. Although the first Australian patent for an invention involving a living organism was granted in 1921, the first patent claiming a pure cultured bacterium was allowed in 1976 to Ranks Hovis McDougall Ltd. (1976) (46 AOJP 3915). However, the patent was not granted before the question of whether living organisms are patentable was considered. This case applied the principles of NRDC and remains authority on the patentability for biological materials. Although this case specifically dealt with microorganisms, the principles have been extended to all living organisms and are still applicable today. In Ranks Hovis McDougall Ltd. it was held that (IP Australia 2002; 2.7.1):

- a claim to a new organism may not be rejected on the ground that it is something living;

- a claim to a new variant must have improved or altered useful properties and not merely altered morphological characteristics that have no effect on the working of the organism;

- a naturally occurring organism is not patentable per se, as it represents a discovery, not an invention;

- a claim to a pure organism culture would satisfy the requirements of intervention, or an artificially created state of affairs.

The evolving and expanding nature of the "manner of manufacture" test has also been highlighted when applied by the Australian courts and IP Australia to human genes, DNA, tissues, and cell lines. More recently this test was considered in relation to isolated DNA in Cancer Voices Australia v. Myriad Genetics Inc. (2013) (FCA 65). The Federal Court of Australia held that "even if the physical properties of the material have not changed, the removal of the material from its natural environment and its separation from other cellular components may still give rise to what might reasonably be described as an artificial state of affairs" (Cancer Voices Australia v. Myriad Genetics Inc. (2013) (FCA 65 at 104)). The court went on to highlight that a nucleic acid in its natural state does not exist outside of the cell and that an isolated nucleic acid is the product of human intervention, and therefore a manner of manufacture (Cancer Voices Australia v. Myriad Genetics Inc. (2013) (FCA 65 at 108)).

Currently, IP Australia applies the same reasoning to human cells in that a cell in its natural environment is not patentable per se. However, an isolated cell or cell line may be patentable if a specific use for the isolated cell or cell line is disclosed, such as its use in the diagnosis or treatment of a specific disease or industrial process: "A human cell line is different from naturally occurring cells in the human body. It is capable of continuous propagation in an artificial environment by continual division of the cells, unlike naturally occurring cells which die after a limited number of divisions." ${ }^{3}$ However, IP Australia acknowledges that there exists a "gray area" and as such has adopted a policy whereby applications that fall into this gray area must be referred to a supervising examiner, who will then discuss the matter with the deputy commissioner (IP Australia 2002; 2.9.5).

In line with the approach taken by IP Australia in relation to cells and cell lines in general, specific types of stem cells are considered to meet the test for manner of manufacture and

\footnotetext{
${ }^{3}$ IP Australia, "Submission to House of Representative Standing Committee on Legal and Constitutional Affairs Inquiry into Scientific, Ethical and Regulatory Aspects of Human Cloning and Stem Cell Research," Commonwealth of Australia, www.aph.gov.au/Parliamentary_Business/ Committees/House_of_Representatives_Committees?url= laca/humancloning/submiss.htm, as at December 6, 2013.
} 
are therefore patentable. However, human embryonic stem cells fall into the gray area of patentability, largely because of statutory exclusions (discussed in the section Statutory Exclusions). The types of products and processes that are typically claimed, and often allowed, in stem cell patent applications include:

- isolated stem cells themselves;

- stem cell lines;

- methods for culturing;

- differentiated and genetically modified stem cells;

- therapeutic applications.

\section{Statutory Exclusions}

\section{Section 18(2): Patentable Subject Matter}

Prior to the introduction of the Patents Act 1990 (Cth), there was no legislative provision in Australia that prevented human beings, and their genetic material, from being patented. However, "human beings and the biological processes for their generation" are now explicitly excluded under section 18(2) and are therefore not patentable.

Although the exact scope of section 18(2) remains unclear, IP Australia has clearly outlined several biological inventions that are excluded from patenting, including (IP Australia 2002; 2.9.5):

- human beings, fetuses, zygotes, blastocysts, embryos, fertilized ova, and equivalents;

- totipotent human cells;

- methods of in vitro fertilization;

- processes for cloning at the four-cell stage or by replacing nuclear DNA;

- processes that involve the creation of a human embryo regardless of the manner in which it was generated, including, but not limited to, fertilization of gametes and nuclear transfer.

Totipotent human stem cells are excluded because of their capacity to develop into a complete human being. In contrast, pluripotent stem cells, descendants of totipotent cells, are not excluded as they do not have the capacity to generate a human being. Adult stem cells per se and processes for their isolation from nonembryonic tissues and organs are also not excluded as they do not have the capacity to develop into a human being.

Interestingly, there are also a number of inventions considered by IP Australia not to contravene section 18(2), and therefore constitute patentable subject matter, including:

- processes for cryopreservation of gametes;

- methods for preimplantation genetic analysis of gametes;

- processes or methods for determining developmental progress or viability of a fertilized ovum, blastocyst, or embryo, by analysis of culture or incubation media.

There remains considerable ambiguity regarding section 18(2) with respect to what constitutes generation of a "human being." To date there have been no judicial considerations of section 18(2) and only two Australian Patent Office decisions.

In Fertilitescentrum $A B$ and Luminis Pty Ltd. (2004) (APO 19), IP Australia "recognised a human being as being in the process of generation from the time of the processes that create a fertilised ovum up until the time of birth." This decision confirmed that "processes, wholly biological, that result in a human being-beginning with fertilisation and ending with birth" are excluded from patentability. It is evident that in applying section 18(2) IP Australia regards a human being as coming into existence at the point of activation of the oocyte. Therefore, it is sufficient that only "a step along the path of generating a human being" be taken for a process to be excluded from patentability. IP Australia has extended this interpretation to include parthenogenic blastocysts. Parthenogenic blastocysts are artificially activated and do not have the capacity to develop fully into a human being because of the lack of paternal DNA. However, IP Australia considers that by activating an oocyte an intermediate step "along the path of generating a human being" has been taken. 
Consequently, parthenogenic blastocysts are excluded under section 18(2).

In an extension of Fertilitescentrum $A B$ and Luminis Pty Ltd. (2004), IP Australia in Woo-Suk Hwang $(2004)^{4}$ held that interspecies hybrids or chimeras are not patentable because the presence of human nuclear DNA in a cell is sufficient to confer "human being" characteristics on these constructs.

\section{Section 50(1): Contrary to Law}

Australia's legislative scheme provides a principle in favor of patenting of inventions while allowing exclusions for ethical reasons. Under the Patents Act 1990, Australia has maintained provisions under section 50(1) that allow the commissioner to refuse to grant patents that are "contrary to law."

Relevant law that can be invoked under section 50(1) includes the Research Involving Human Embryos Act 2002 (Cth) and Prohibition of Human Cloning for Reproduction Act 2002 (Cth). These acts have further limited the ability to conduct stem cell research in Australia and stipulate that embryonic stem cells may only be obtained from surplus assisted reproductive technology (ART) embryos. That is, only an embryo that is created by reproductive techniques for the use in ART treatment but that has been determined to be excess to the needs of the female and her spouse can be used for stem cell research in Australia. ${ }^{5}$ Further, since June 2003 the ability to conduct research on ART embryos requires a statutory license that is granted by the Embryo Research Licensing Committee of the National Health and Medical Research Council (NHMRC) under strict guidelines. ${ }^{6}$ Currently there are 10 licenses approved in Australia, held by Genea; Melbourne IVF and Monash Institute of Medical Research

\footnotetext{
${ }^{4}$ Woo-Suk Hwang (2004) (APO 24).

${ }^{5}$ Research Involving Human Embryos Act 2002 (Cth), s 9.

${ }^{6}$ Research Involving Human Embryos Act 2002 (Cth), s 2; and National Health and Medical Research Council, NHMRC Embryo Research Licensing Committee Information Kit, www.nhmrc.gov.au/_files_nhmrc/publications/attach ments/hp56_amended.pdf, as at December 6, 2013.
}

( joint license); and Fertility Australia, with the latest expiry of June $2015 .^{7}$

Although relevant to the derivation of embryonic stem cells, it is important to note that this legislation does not apply to stem cell lines established prior to 2002 or those imported into Australia. Prior to the introduction of this legislation, approximately 71 human embryonic cell lines existed and many people argued that this was sufficient to conduct research on and for the development of stem cell therapies. However, many of these existing stem cell lines are subject to patent protection, restricting researchers' freedom to operate (Rimmer 2003). Furthermore, there was concern about the lack of genetic diversity, contamination through inappropriate culture conditions, and limited quality and quantity of these existing lines (Murugan 2009).

If an invention involves the production of a human embryo that contravenes the Prohibition of Human Cloning for Reproduction Act or the Research Involving Human Embryos Act, the corresponding patent application may be refused at the discretion of the commissioner under section 50(1). Similar to section 18(2), there have been no judicial considerations surrounding section 50(1) in relation to human beings; however, in a landmark move, IP Australia sought to apply this regulation to stem cell technologies for the first time in Woo-Suk Hwang. Section 50(1) was applied as the claimed invention was contrary to section 20 of the Prohibition of Human Cloning Act 2002, which specifically opposes the generation of a chimeric or hybrid embryo.

In recent IP Australia examination decisions concerning parthenotes, IP Australia has regarded section 50(1) alongside section 18(2), with applications being refused for being contrary to the Research Involving Human Embryos Act under section 10A, which excludes embryos created through activation by means other than

\footnotetext{
${ }^{7}$ National Health and Medical Research Council, "Database of Licences authorising the use of excess ARTembryos," www.nhmrc.gov.au/health-ethics/human-embryos-andcloning/database-licences-authorising-use-excess-art-emb ryos, as at December 6, 2013.
} 
by fertilization of a human egg by a human sperm.

\section{THE FUTURE OF STEM CELL PATENTS IN AUSTRALIA}

The ability to influence and direct the growth of stem cells in the laboratory is already well recognized. The ability to grow blood cells, insulin-producing cells, and heart muscle cells from human embryonic stem cells has been demonstrated by Australian researchers at Monash University and the Murdoch Children's Research Institute (Mummery et al. 2012; Nostro et al. 2012; Yu et al. 2012). Growing these cells in the laboratory gives researchers a better understanding of how normal tissues develop and offers the opportunity to study human disease. Stem cell research also offers potential for the development of cellular therapies for incurable, often fatal, diseases. In Australia there are currently 18 stem cell clinical trials in operation (Stem Cells Australia 2013). None of the current studies involve the use of embryonic stem cells, with a majority of the trials employing adult bone marrow stem cells or umbilical cord stem cells.

It is evident from current research efforts that much of the focus is on adult stem cells. As these cells are derived from adult tissue sources, their use in the laboratory and therapeutic application is much less controversial. Adult stem cell therapies have for many years been used to successfully treat leukemia through the use of bone marrow transplants. A number of other stem cell-based therapies are emerging, with a focus largely on regenerative applications. In 2008 the first human organ grown from adult stem cells was successfully transplanted (Macchiarini et al. 2008). This process involved the use of autologous adult stem cells; however, the potential therapeutic applications with allogeneic stem cells are wide reaching. Recently, U.S.-based Osiris Therapeutics, acquired by Mesoblast Inc. in 2013, obtained the first stem cell drug patent in Australia for the administration of mesenchymal stem cells for the treatment of inflammatory conditions involving the gastrointestinal tract, including Crohn's disease and ulcerative colitis. This off-the-shelf stem cell product (Prochymal) was the first stem cell drug to gain international regulatory approval.

Recent scientific developments have led to the ability to reprogram adult cells to induced pluripotent stem cells (iPSCs) by genetic manipulation. Human iPSCs have been shown to have similar morphological characteristics to human embryonic stem cells, including proliferative capacity, surface antigens, gene expression, epigenetic status, and telomerase activity. The ability to confer this stem cell potential on almost all mature cells has the potential for wide-reaching therapeutic applications. Because iPSCs are not derived from human embryos, they offer a less complicated source of human pluripotent cells. However, successful reconstitution of viable murine embryos from iPSCs using tetraploid complementation has been reported (Tam and Rossant 2003; Kang et al. 2009) and indicates the possibility of direct cloning with these cells. Currently, 60 applications directed toward iPSC technologies have been lodged with IP Australia, with only four applications granted and 54 awaiting examination. However, until these applications have been examined, the patent landscape surrounding iPSCs in Australia remains largely undefined.

Despite Australia's more liberal view on embryonic stem cell research, there remains an ongoing political and social debate about the legitimacy of such research. In 2010 the Patent Amendment (Human Genes and Biological Materials) Bill was proposed to Federal Parliament by Liberal senator Bill Heffernan. The proposed bill sought to fundamentally amend section 18(2) of the Patents Act 1990 by expressly excluding from patentability "biological materials including their components and derivatives, whether isolated or purified or not and however made, which are identical or substantially identical to such materials as they exist in nature." ${ }^{\prime}$ Furthermore, human biological materials were defined to "include DNA, RNA, pro-

${ }^{8}$ Patent Amendment (Human Genes and Biological Materials) Bill 2010 (Cth). 
teins, cells and fluids." This bill was subjected to an intense parliamentary debate, and based on the recommendation of a Senate committee report, it was unsuccessful. However, the debate in Australia is by no means over. Since then, major changes to the Patents Act 1990 have been introduced with the passing of the Intellectual Property Laws Amendment (Raising the Bar) Bill 2011. These changes included raising the standard of granted patents by increasing the inventive step threshold and support requirements for applications. Despite this high threshold of requirements, it appears to be insufficient for those in favor of banning biological patents.

In 2011 the Advisory Council on Intellectual Property (ACIP) (2010) released its report on patentable subject matter. Interestingly, it was recommended that the principles on manner of manufacture developed by the High Court in NRDC (outlined above in the section Section 18(2): Patentable Subject Matter) be adopted into the legislation to clearly define the principles of inherent patentability. Although stem cell patents were considered, as well as the impact that more rigid guidelines would have, no definitive framework regarding exclusion criteria was recommended. These recommendations, or lack thereof, are reflected in the Intellectual Property Laws Amendment (Raising the Bar) Act 2012, implemented in 2013, in which no additional exclusions to patentable subject matter, in particular stem cells, were introduced.

Interestingly, in the $2011 \mathrm{ACIP}$ report it was suggested that the section 50(1) "contrary to law" provision is not compliant with Article 27 of the TRIPs Agreement. TRIPs (Agreement on Trade-Related Aspects of Intellectual Property Rights) states that an invention may not be excluded from patentability "merely because the exploitation is prohibited by their law." Therefore, the commercial exploitation must be contrary to ordre public or morality. Although ACIP recommended the inclusion of a general exclusion principle on "ethical grounds," it was not amended under the recent Raising the Bar Act. It is interesting to note that New Zealand repealed its provision equivalent to section 50 (1) and replaced it with a discretionary provision to refuse applications that are contrary to morality. Schedule 1 of Australia's Patents Regulations 1991 (Cth) seeks to amend this deficiency and provides that patent applications must not contain material that is "contrary to morality or public order." The inclusion of this provision brings Australian patent law in line not only with our TRIPs agreement but also with our European counterparts. ${ }^{9}$

The debate regarding the patenting of biological materials is also far from over in Australia. Cancer Voices v. Myriad Genetics Inc. (2013) (FCA 65) is currently on appeal to the Full Federal Court of Australia. The outcome of this appeal is sure to have wide-ranging effects on the patentability of naturally occurring biological substances in Australia, including stem cells.

\section{CONCLUDING REMARKS}

In Australia biological materials such as stem cells are considered patentable subject matter if they meet the statutory requirements of a "manner of manufacture." This provision is broad and general and is intended to encourage technological developments that are by their nature unpredictable. Thus, the categories of inventions that satisfy the test have expanded over time, including living microorganisms, isolated DNA molecules, and stem cells. It is clear, however, that certain biological materials are expressly excluded from patenting under the Patents Act 1990 section 18(2). This provision expressly excludes human beings, from the point of oocyte activation and processes, beginning with fertilization and ending with birth, from patentable subject matter. Totipotent stem cells are also excluded on the basis that they have the capacity to develop into human beings. Furthermore, stem cell applications that involve the generation of a human embryo may be refused under section 50(1) for being contrary to law. However, the lack of Australian judicial consideration to date on these provisions has meant that the scope and potential impact on stem cell patents remains unclear.

\footnotetext{
${ }^{9}$ European Patent Convention (EPC) Article 53(a) and Rule $28(\mathrm{c})$
} 


\section{REFERENCES}

Advisory Council on Intellectual Property (ACIP). 2010 Patentable subject matter, final report. Commonwealth of Australia, Canberra, Australia. www.acip.gov.au/ pdfs/ACIP_Final_Report_Patentable_Subject_Matter_ Archived.pdf.

Altman J, Das GD. 1965. Autoradiographic and histological evidence of postnatal hippocampal neurogenesis in rats. J Comp Neurol 124: 319-335.

Bodkin C (Colin Lewis). 2014. Patent law in Australia, 2nd ed., p. 62. Thomson Reuters, Pyrmont, N.S.W., Australia.

Evans M, Kaufman M. 1981. Establishment in culture of pluripotent cells from mouse embryos. Nature 292: $154-156$.

IP Australia. 2002. Australian Patent Office patent manual of practice \& procedure, Vol. 2, [2.9.5]. National Access and Development. Palgrave Macmillan, Basingstoke, UK.

Kang L, Wang J, Zhang Y, Kou Z, Gao S. 2009. iPS cells can support full-term development of tetraploid blastocystcomplemented embryos. Cell Stem Cell 5: 135-138.

Lewis PD. 1968. Mitotic activity in the primate subependymal layer and the genesis of gliomas. Nature 217: 974975.

Liu S, Dontu G, Wicha MS. 2005. Mammary stem cells, selfrenewal pathways, and carcinogenesis. Breast Cancer Res 7: 86-95.

Macchiarini P, Jungebluth P, Go T, Asnaghi MA, Rees LE, Cogan TA, Dodson A, Martorell J, Bellini S, Parnigotto PP, et al. 2008. Clinical transplantation of a tissue-engineered airway. Lancet 372: 2023-2030.

Martin G. 1981. Isolation of a pluripotent cell line from early mouse embryos cultured in medium conditioned by teratocarcinoma stem cells. Proc Natl Acad Sci 78: 76347638.

Mummery CL, Zhang J, Ng ES, Elliott DA, Elefanty AG, Kamp TJ. 2012. Differentiation of human embryonic stem cells and induced pluripotent stem cells to cardiomyocytes: A methods overview. Circ Res 111: 344-358.

Murrell W, Féron F, Wetzig A, Cameron N, Splatt K, Bellette B, Bianco J, Perry C, Lee G, Mackay-Sim A. 2005. Multipotent stem cells from adult olfactory mucosa. Dev Dyn 233: $496-515$.

Murugan V. 2009. Embryonic stem cell research: A decade of debate from Bush to Obama. Yale J Biol Med 82: 101103.

Nostro MC, Sarangi F, Ogawa S, Holtzinger A, Corneo B, Li X, Micallef SJ, Park IH, Basford C, Wheeler MB, et al. 2012. Pancreatic differentiation (ed. StemBook). The Stem Cell Research Community, StemBook. doi/ 10.3824/stembook.1.72.1, http://www.stembook.org.

Phinney DG, Prockop DJ. 2007. Concise review: Mesenchymal stem/multipotent stromal cells: The state of transdifferentiation and modes of tissue repair-Current views. Stem Cells 25: 2896-2902.

Rimmer M. 2003. The attack of the clones: Patent law and stem cell research. J Law Med 10: 488-505.

Stem Cells Australia. 2013. Trials in Australia. http://www .stemcellsaustralia.edu.au/About-Stem-Cells/trials-inaustralia.aspx.

Tam P, Rossant J. 2003. Mouse embryonic chimeras: Tools for studying mammalian development. Development 130: 6155-6163.

Thomson JA, Itskovitz-Eldor J, Shapiro SS, Waknitz MA, Swiergiel JJ, Marshall VS, Jones JM. 1998. Embryonic stem cell lines derived from human blastocysts. Science 282: 1145-1147.

Van Der Flier LG, Clevers H. 2009. Stem cells, self-renewal, and differentiation in the intestinal epithelium. Annu Rev Physiol 71: 241-260.

Yu QC, Hirst CE, Costa M, Ng ES, Schiesser JV, Gertow K, Stanley EG, Elefanty AG. 2012. APELIN promotes hematopoiesis from human embryonic stem cells. Blood 119: 6243-6254. 


\section{$\&_{\mathrm{CSH}}^{\infty} \&$ Cold Spring Harbor

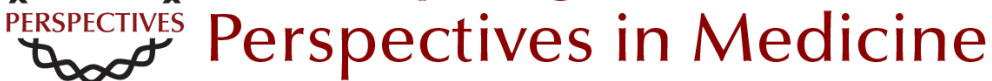

\section{The Patentability of Stem Cells in Australia}

Jenny Petering and Prue Cowin

Cold Spring Harb Perspect Med 2015; doi: 10.1101/cshperspect.a020966 originally published online July 1,2015

\section{Subject Collection Intellectual Property in Molecular Medicine}

Patentability of Stem Cells in the United States Sarah E. Fendrick and Donald L. Zuhn, Jr.

Inventorship and Authorship Antoinette F. Konski and Linda X. Wu

The Patentability of Stem Cells in Australia Jenny Petering and Prue Cowin

Impact of America Invents Act on Biotech Intellectual Property

Amanda Murphy, Michael Stramiello, Jonathan Stroud, et al.

Introduction to Intellectual Property: A U.S.

Perspective

Amanda Murphy, Michael Stramiello, Stacy Lewis, et al.

The Role of Regulatory Agencies and Intellectual Property: Part I

Kevin E. Noonan

Canada's Patented Medicines (Notice of Compliance) Proceedings and Intellectual

Property

Henry Bian and Conor McCourt

Patentability of Genes: A European Union

Perspective

Paul Cole
The Impact of Myriad on the Future Development and Commercialization of DNA-Based Therapies and Diagnostics

Michele Wales and Eddie Cartier

Protecting Traditional Knowledge Related to

Biological Resources: Is Scientific Research

Going to Become More Bureaucratized?

Prashant Reddy and Malathi Lakshmikumaran

Protecting Trade Secrets in Canada

Noel Courage and Janice Calzavara

Inherent Anticipation in the Pharmaceutical and

Biotechnology Industries

Michael Goldman, Georgia Evans and Andrew Zappia

The Role of Regulatory Agencies and Intellectual

Property: Part II

Kevin E. Noonan

Baseball Bats and Chocolate Chip Cookies: The Judicial Treatment of DNA in the Myriad Genetics Litigation lan Binnie and Vanessa Park-Thompson

The Impact of Myriad and Mayo: Will

Advancements in the Biological Sciences $\mathrm{Be}$

Spurred or Disincentivized? (Or Was Biotech

Patenting Not Complicated Enough?) Jennifer Gordon

Trade Secrets in Life Science and Pharmaceutical Companies

Tara Nealey, Ronald M. Daignault and Yu Cai

For additional articles in this collection, see http://perspectivesinmedicine.cshlp.org/cgi/collection/ 